\title{
NMRガスイメージング法によるコークス気孔での 反応解析
}

\author{
齋藤 公児 $*$ ・国友 和也 $* 2 \cdot$ 福田 耕一 $* 2 \cdot$ 加藤 健次 $* 2 \cdot$ 古牧 育男 $* 3$ \\ Analysis of Chemical Reaction in the Voids of Cokes Using NMR Gas Imaging \\ Koji SaIto, Kazuya Kunitomo, Kouichi FukUda, Kenji KatoH and Ikuo Komaki
}

\begin{abstract}
Synopsis : The pore structure is very critical and sensitive to react with $\mathrm{CO}_{2}$ in the case of cokes. But it is very difficult to detect the pore structure of cokes with nondestructive and high resolution because conventional porosimeter method can't detect macro pore (over $400 \mu \mathrm{m}$ ), and at the same time with destructive. We are at first demonstrating 3D-SPRITE imaging to detect the pore structure using $\mathrm{SF}_{4}$ gas, before and after $\mathrm{CO}_{2}$ reaction, (over $1 \mu \mathrm{m}$ ) with non destructive and the same pores, and then clarify the reaction mechanism. We found that the reaction rate of the cokes with $\mathrm{CO}_{2}$ depends on the pore size and the critical pore size is over $100 \mu \mathrm{m}$.
\end{abstract}

Key words: NMR imaging; cokes; pore structure.

\section{1.はじめに}

高炉におけるコークスは，還元剤，熱源，炉内の通気や 通液性の確保など多くの役割を果たしており，とくにその

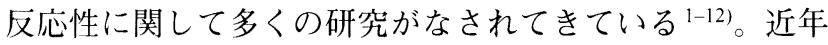
の高炉への微粉炭吹込み量の増加に伴い，高炉炉下部に コークス粉が蓄積する現象 ${ }^{13)}$ が指摘されており，コークス の反応過程解析への興味はますます高まっている。コーク スはいわゆる多孔質材料である。反応に重要な関わりをも つ気孔を多く含むため，その反応前後での気孔の解析をす るために，従来は水銀ポロシメータ法やX X 線 CT 法や反射 型の顕微鏡などが利用されている。しかし，水銀ポロシ メータ法は気孔の間接的な観測法であり，また水銀を利用 する破壊計測であり，かつ装置特性や測定条件によっては 得られる結果が異なる場合が多い14)。また，水銀ポロシ メータ法は数 $100 \mu \mathrm{m}$ 以上の気孔を正確に測定できないこ とを数多くの場で指摘15-17)されており，この程度の気孔の 多いコークスには不適である。さらに $\mathrm{CO}_{2}$ での反応後は基 質が脆弱化しており，水銀ポロシメータ法で高い圧力をか けた際のコークス基質への悪影響が賏念される。対して通 常の樹脂を用いた反射型顕微鏡法では，気孔を直接観測で きる利点はあるが，基質である炭素そのものに組織が存在 するため, 得られる輝度の範囲が広くなり，画像処理で気 孔面積を求めることが困難な場合が多い。また，最近，柏 谷ら ${ }^{16)}$ はこの問題点を克服するために，蛍光塗料を樹脂に 添加し真空中でコークスに浸透させて，紫外線照射下で顕
微鏡観察する方法を提案している。この方法で非常に鮮明 に気孔構造を捉え，コークス中に多くの数 $100 \mu \mathrm{m}$ 以上の 気孔が存在していることを明らかにしているとともに，反 応前後の気孔の変化を議論している。しかし, 残念ながら 破壊計測のため同一試料を観測できていないので，速度論 的な解析がなされていない。

非破壊計測方法の代表としてX線 CT 法があるが，一般 的利用可能な装置の分解能はせいぜい数 $100 \mu \mathrm{m}$ 程度と低 く ${ }^{19,20)}$ ，また観測している対象は気孔を形成している基質 であり，気孔情報を得るには基質情報を求めて計算する必 要がある。同時に基質構造が3次元的に存在しているため， $\mathrm{CT}$ 法の原理として2次元的なデータの取り込みでは虚像

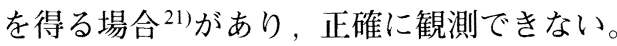

NMRイメージングは非破壊測定でかつ3次元的に情報 をとり込むことができるため，多くの材料解析への応用が 展開されつつあり 22-24)，すでにわれわれはコークスと同様 の多孔質体である耐火物レンガの気孔解析への適用に成 功 ${ }^{25,26)}$ しており，この結果は日本鉄鋼協会で耐火物の組織 研究会の最終報告書にも気孔観察に有効な方法として記載 されている ${ }^{15)}$ 。そこで，本研究では，「コークスの気孔」 に着目し，耐火物観測の際に確立した手法をさらに工夫す ることで, 全く同じ気孔の反応前後での構造変化を高分解 能NMRガスイメージング法で測定し，気孔サイズ，気孔 存在位置ごとにおける解析およびコークスの3次元気孔構 造解析を通して，気孔での反応メカニズムを検討し，興味 深い結果を得たので報告する27)。

平成 14 年.5月14日受付 平成 14 年6月26日受理 (Received on May 14, 2002; Accepted on June 26, 2002)

* 新日本製鐵（株）先端技術研究所 (Advanced Technology Research Lab., Nippon Steel Corp., 20-1 Shintomi Futtsu 293-8511)

*2 新日本製鐵 (株) 環境・プロセス研究開発センター (Environment \& Process Technology Center, Nippon Steel Corp.)

*3 北九州市立大学国際環境工学部 (Faculty of Environmental Engineering, Kitakyushu University) 


\section{2. 実験}

\section{$2 \cdot 1$ 試料}

石炭は粘結炭の代表種である NO. 2 炭（ash; 9.7\%, VM; $24 \%$, total carbon; $79.8 \%$, hydrogen; $4.4 \%$, nitogen; $1.8 \%$, oxgen; $3.7 \%$, sulfer; $0.6 \%$, MF; 2.8 (log ddpm), 粒度： $3 \mathrm{~mm}$ 以 下）装入密度 $0.85\left(\mathrm{t} / \mathrm{m}^{3}\right)$ で小型試験炉にてコークス化し， Fig. 1 に示すように, 半径約 $10 \mathrm{~mm}$, 高さ $30 \mathrm{~mm}$ の円柱状に くりぬき成形し，試料として用いた。その試料を Fig. 2 に 示すように，温度とガス濃度を可変できる炉を利用して， 反応履歴を与えながら全く同一試料を反応させた。以後， 本論文中では，反応前試料について NO. $2-0,900^{\circ} \mathrm{C}$ 終了後 の試料を NO. 2-1（重量低下率 $1.8 \%$ )，1100 ${ }^{\circ} \mathrm{C}$ 終了後の試 料を NO. 2-2（重量低下率 $4.5 \%$ ），1300 ${ }^{\circ} \mathrm{C}$ 終了後の試料を NO. 2-3（重量低下率 $12.3 \% ）, 1400^{\circ} \mathrm{C}$ 終了後の試料を NO. 2-4（重量低下率 $20.9 \%$ ）とする。

\section{$2 \cdot 2$ NMRイメージング測定}

前述した試料(NO. 2-0〜NO. 2-4)について，下記の方法 で気孔の3次元測定を実施した。NMRイメージングによ る気孔の測定は自作のイメージングユニットを付帯してい る日本電子製 $\alpha-400 て ゙$ て行った。材料中に存在する気孔は NMRでは基本的には観測できないが，観測対象媒体とし て $\mathrm{SF}_{4}$ ガスを選び，コークスの気孔中に適当 $\left(5 \cdot 10^{5} \sim 1 \cdot 10^{6}\right.$

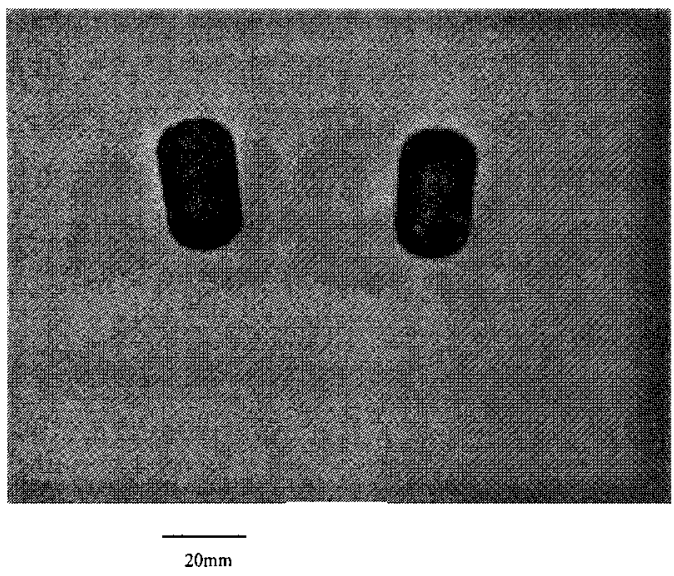

Fig. 1. Representative cokes sample.

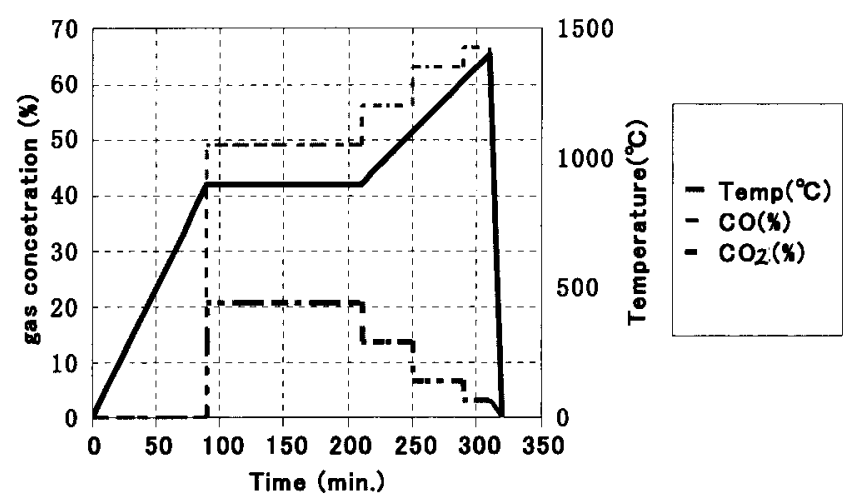

Fig. 2. Temperature and gas pattern of experiments.
Pa) な圧力で封入することで，観測対象核はF $(376.4 \mathrm{MHz})$ で気孔観測が実現できる。試料をWilmard（社）製のテフ ロンシールバルブ付き試料管に入れ， $\mathrm{SF}_{4}$ ガスを圧力をか けて封入した後，テフロンシールバルブを閉めることで， $\mathrm{SF}_{4}$ ガスは試料中に入った状態となり，それをそのまま亿 メージング測定用試料とした。 $\mathrm{SF}_{4}$ ガスはその特性上, 安 定でかつコークスとの反応性や吸着性も全くなく不活性 で，かつ基本的にはコークス中に $\mathrm{F}$ 原子が存在しないため， $\mathrm{NMR}$ 中で観測された $\mathrm{F}$ 核はすべて $\mathrm{SF}_{4}$ ガス由来と考元るこ とができ，気孔の判定が容易となる。また $T_{1}$ (スピンー格 子緩和緩和時間）が 0.1 秒程度と非常に短いために，繰り 返し時間が短縮できるメリットもある。耐火物を観測する 際には，溶媒を観測対象として利用していた。しかし溶媒 の場合は材料との濡れ性の問題があり，また細孔の奥まで 浸透しにくいなどの欠点があったが，ガスを利用すること でこの問題点を克服できた。試料サイズは, Fig. 1に示す ように $\phi 20 \mathrm{~mm} \cdot 30 \mathrm{~mm}$ で，そのサイズに合わせて，F核が 検出できるようなサドル型検出コイルを設計・製作した。 実験のスキームを Fig. 3に示す。

コークスのような基質の材料が不均一でかつAshなどを 含む材料の場合，通常のスピンエコー法では磁化率の差の 影響を受けて正確なイメージ像が撮れないが，今回 SPRITE法 ${ }^{24)}$ 適用することでその問題点を克服できた。 そのパルスシーケンスをFig. 4に示す。 SPRITE法(SinglePoint Ramped Imaging with $T_{1}$ Enhancement)は従来のスピン エコー法のように帯域選択パルスに依存して抢らず，RF （ラジオ波）パルスの励起域に依存している。よって励起 に使用するパルス幅の逆数は試料の大きさ $(\mathrm{cm})$ と磁場勾 配量 $(\mathrm{T} / \mathrm{m})$ の積よりも大きくなくてはならない。同時に, SPRITE法は純粋に位相エンコードのみでのイメージング 技術で, 従来法の位相打よび周波数エンコードの混合型と

\section{Sample Tube with vacuum seal}

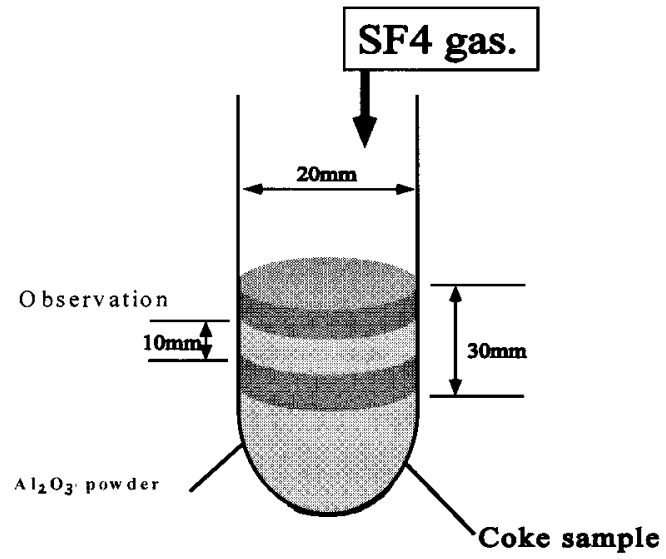

\section{Sample scheme for Imaging}

Fig. 3. Experimental sample scheme. 


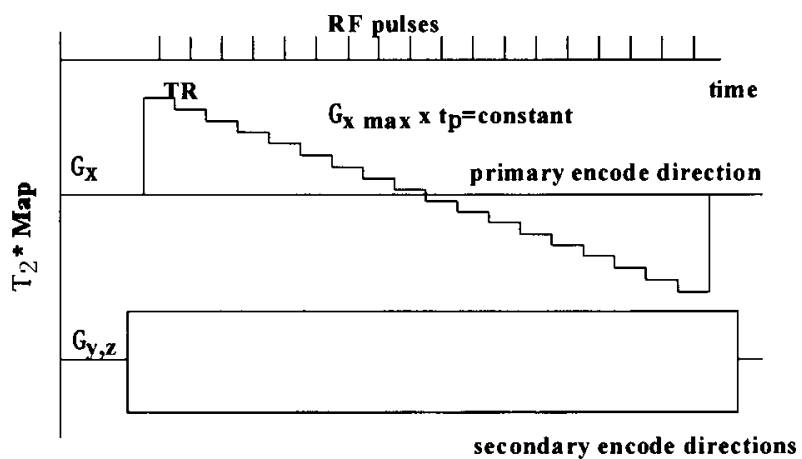

Fig. 4. Pulse sequence of SPRITE imaging.

は異なる。信号は磁場勾配が行われている間に，短い励起

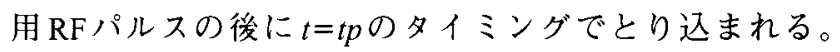
よって, 周波数エンコードを用いた従来のスピンエコー法 と異なり， $B_{0}$ (静磁場) の不均一性や岩石に多く存在する 磁化率の異なる物質の影響や化学シフトの差などから生じ るイメージ像の歪みなどの影響を全く受けない。分解能は， $\mathrm{SF}_{4}$ ガスのような $T_{2}^{*}$ (自由誘導減衰の時定数) の短い試料 でさえも，単純に試料にかける磁場公配の強さだけで決ま る。つまり, 試料にかける磁場勾配が強いければ強いほど 分解能は高くなる。得られる信号強度 $\mathrm{S}$ はその部分に存在 するフッ素原子の存在密度 $\rho$ で記述でき，式(1)のように 表せる

$$
S=\rho \exp \left(-t p / T_{2}^{*}\right) \times R(x)
$$

ここでR(x)=(1-exp $\left.\left(-T_{R} / T_{1}\right)\right) /\left(1-\cos \theta \exp \left(-T_{R} / T_{1}\right)\right)$.

式( 1$)$ での $R(x)$ から, 試料固有の最短の $T_{1}$ に依存して繰 り返し時間 $\left(T_{R}\right)$ を決定できる。この手法の欠点としては, 磁場勾配を強く発生できる装置が必須であること, および 化学シフト情報を失ってしまうことであるが, 高磁場勾配 発生装置と測定可能なプローブを準備し, 測定条件を最適 化することで, 先の (1)式からわかるように, イメージ像 における信号強度がコークス中の気孔に入った $\mathrm{SF}_{4}$ ガス成 分の存在量として表せるので, 磁化率の異なる試料が多く 混在するコークスなどの定量的な解析には非常に適した測 定法である。2048·2048·128のデータサイズの3次元イ メージ像 (平面方向分解能; $9 \mu \mathrm{m}$, 厚さ方向分解能 $100 \mu \mathrm{m}$ ) を得る場合, 約 38 時間の測定時間であった。最適化され た主な測定条件は，励起パルスは $5 \mu \mathrm{s}$, エコー時間は $100 \mu \mathrm{s}$, 繰り返し時間は $15 \mathrm{~ms}$ でちた。同一面を観測でき るように, 試料中心をいつも観測コイル中心に合うよう設 定した。使用した勾配磁場は， $X$ 軸で $1.46 \mathrm{~T} / \mathrm{m}, Y$ 軸で $1.46 \mathrm{~T} / \mathrm{m}, Z$ 軸で $1.09 \mathrm{~T} / \mathrm{m}$ であった。気孔構造の解析には $\mathrm{PC}$ 上で, CTC (株) 製Visilogを利用し, データの解析方法 は以下の手順で行った。

(1)得られた結果をフーリエ変換し、デジタルな面分解能を $1 \mu \mathrm{m}$ 以下になるように条件を設定。
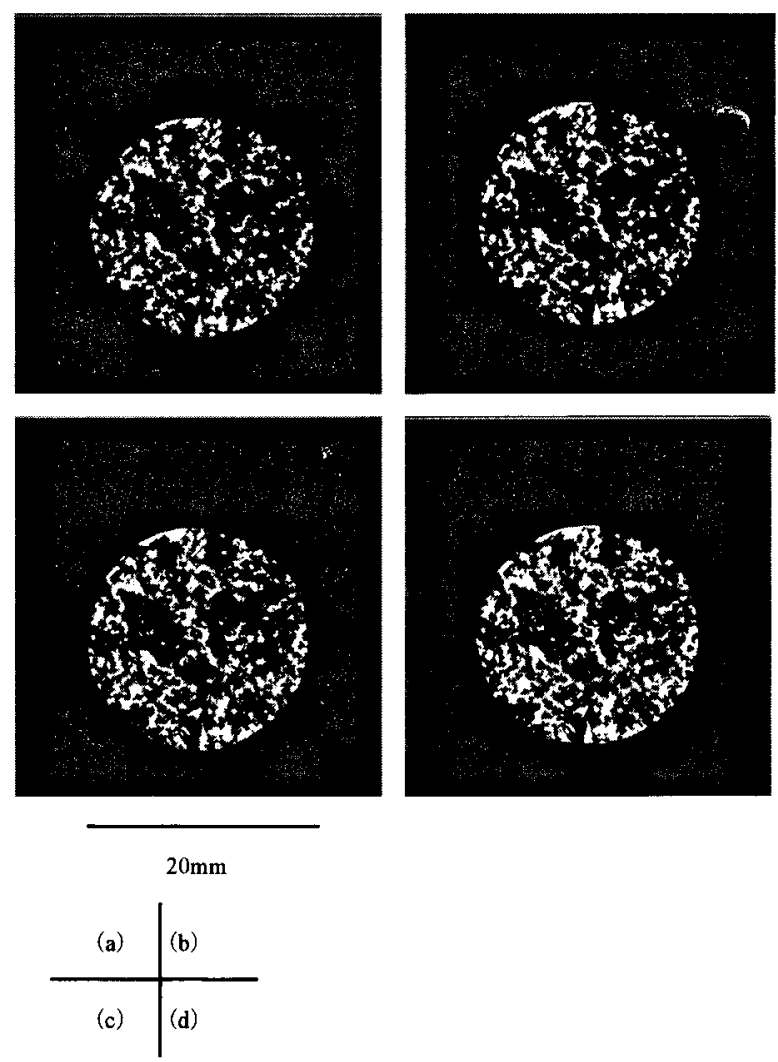

Fig. 5. Representative results of SPRITE images for cokes. (a) NO. 2-0, (b) NO. 2-2, (c) NO. -3, (d) NO. 2-4.

(2)全体の長さ $30 \mathrm{~mm}$ のち, 反応の不均一性を取り除くた

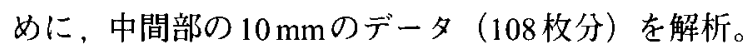

(3)そのデータをVisilog中にとり込み, 画像解析を実施。 気孔径は気孔を楕円と捉えて, その平均值を平均気孔径 と設定した。

\section{3. 結果}

Fig. 5に試料の反応による気孔の全体的な変化を示す。 白く鮮明に観測できているのが気孔で，コークス中に明ら かに不均一に存在していることがわかる。かなり大きな気 孔が存在していることがわかる。また反応が進行するにつ れて気孔が増大および増加している現象が確認できる。部 位ごとの気孔率の変化を明らかにするために, 試料の中心

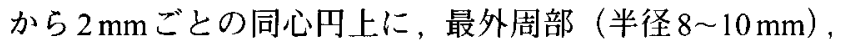
外周部 (半径 $6 \sim 8 \mathrm{~mm}$ ), 中間部 (半径 $4 \sim 6 \mathrm{~mm}$ ), 内周部 (半径 2 4 mm), 最内周部 (半径 $0 \sim 2 \mathrm{~mm}$ ) の 5 つに分割 して，解析を実施した。Fig. 6に部位ごとの気孔率を算出 した結果を示す。この試料では, 反応が進むにつれて外周 から気孔率が増加していくことが明らかで, 内周部や最内 周部は気孔率があまり変化していないことがわかった。こ の傾向は川上らの報告 ${ }^{28)}$ とよく合致している。この試料系 では，コークスの表面反応が全体を支配していると推定で きる。Fig. 7に最外周部 (半徍 8 10 mm), 中間部 (半径 


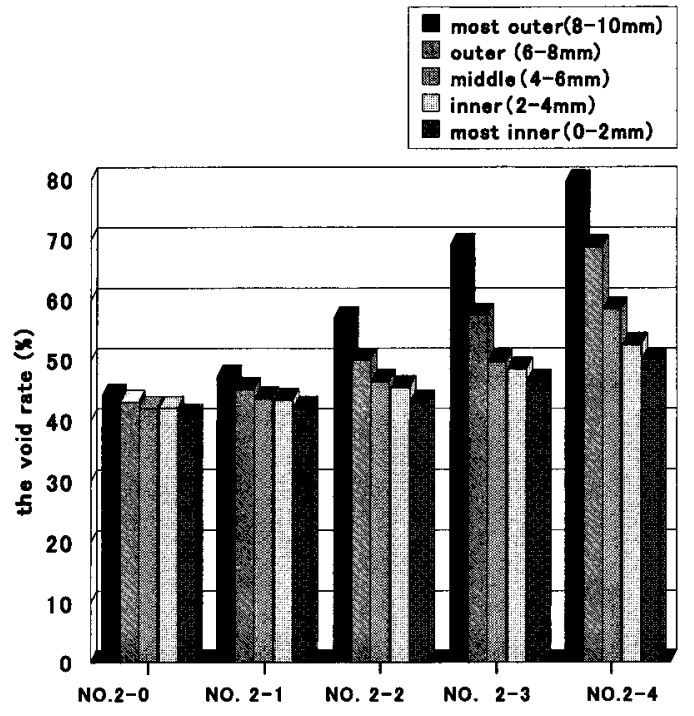

Fig. 6. The void rate at 5 parts of NO. 2-0, NO. 2-1, NO. 2-2, NO. 2-3, NO. 2-4 cokes.
4 6 $\mathrm{mm}$ )，最内周部（半径0〜2 $\mathrm{mm}$ ）の3つの部位ごとに 気孔を定点観測した結果を示す。観測面での気孔が不均一 に存在しているので一義的な比較はできないが，例えば $100 \mu \mathrm{m}$ 程度の気孔に着目すると, 反応が進むにつれて最 外周部は明らかに気孔径が増大している。また気孔径の増 大は，反応が進むことで基質が消費され，近くにある気孔 との合体でさらに拡大していることが明確である。気孔径 の増大の傾向は同心円状に均一に桩大していないことか ら，基質での組織や化学構造などによって反応しやすさが 異なる29,30) と推定できるが，本手法からは気孔構造のみの 情報しか得られないので，推定の域を出ない。対して，最 内周部ではほとんど気孔に変化がないことがわかる。反応 前の試料No. 2-0 と最終的な反応終了後の試料No. 2-4につ いての部位ごとにおける気孔徍存在率をFig. 8 に示す。反 応前は，気孔径の存在率は部位ごとにはあまり差がない。
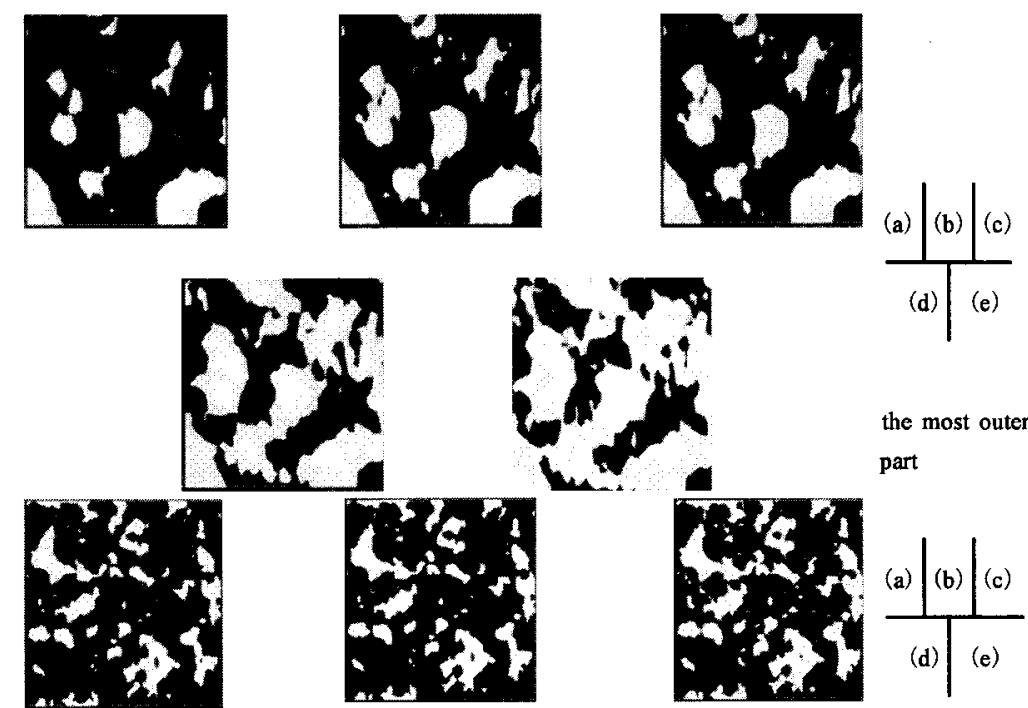

the most outer

part
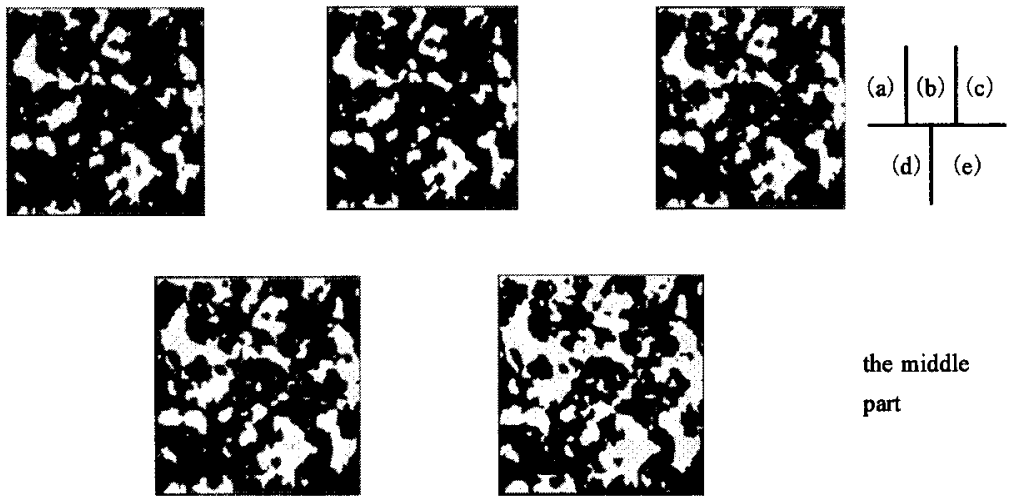

the middle

part
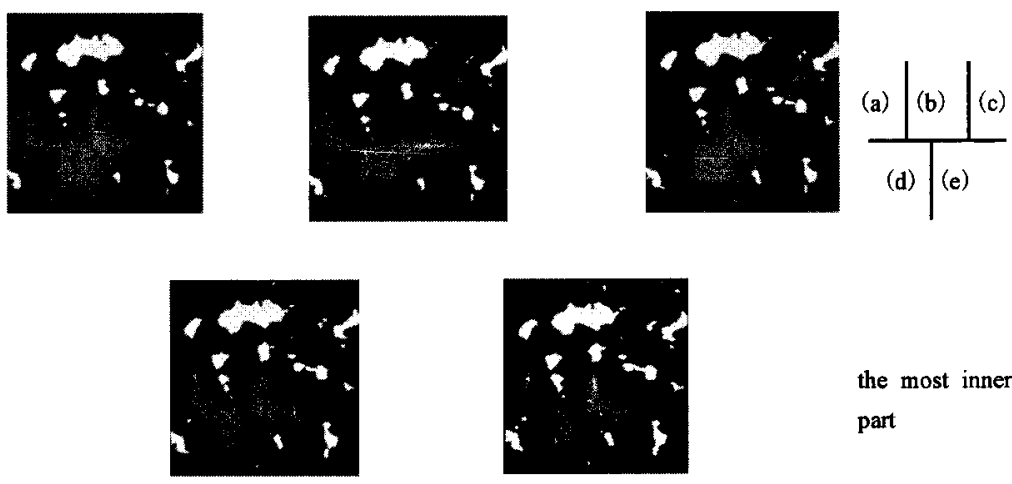

the most inner

part

$1 \mathrm{~mm}$

Fig. 7. Representative results of SPRITE expanded images for the most outer part and the middle part and the most innner part of cokes. (a) NO. 2-0, (b) NO. 2-1, (c) NO. 2-2, (d) NO. 2-3, (e) NO. 2-4. 
NO. $2-0$
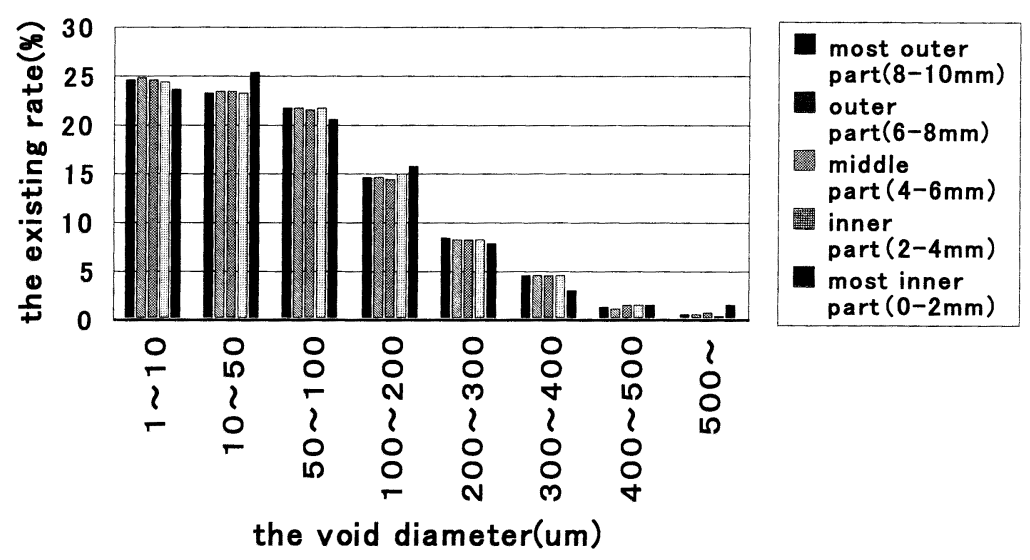

NO. $2-4$

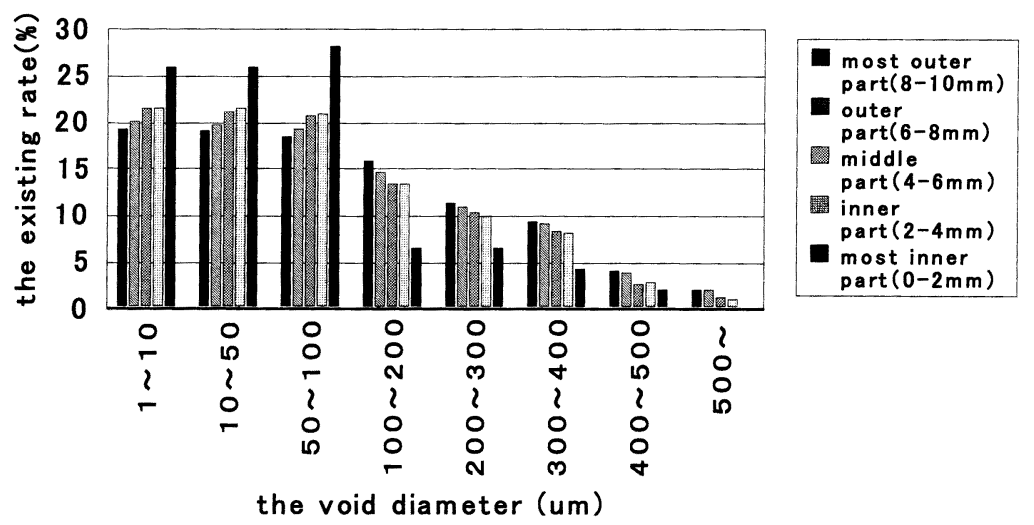

Fig. 8. The existing rate of pore size for NO. 2-0 and NO. 2-4 cokes.

反応終了後は, $100 \mu \mathrm{m}$ 以上の気孔径の存在率が最外周部 や外周部で向上している。先述したように，今回の試料お よび設定した反応条件ではコークスの反応は外周から優先 的に起こっており，非破壊法であるNMRイメージング法 による定点観測が気孔の反応前後の変化を捉えるのに非常 に有効であることがわかる。

この反応変化をさらに詳細に解析するため, 得られた結 果を先に述べた 5 領域（最外周, 外周, 中間, 内周, 最内 周）について, 得られた気孔径に着目し, 変化前の気孔 径； $R 1$, そして変化後の気孔径 $; R 2$ とし,

$$
\left(R 2^{3}\right)-\left(R 1^{3}\right) /\left(R 1^{2}\right)
$$

式( 2)から見掛けの平均変化速度を, 定点観察したすべて の部位および気孔径に関して求めた。その結果を Fig. 9 に 示す。中間, 内周, 最内周部の平均反応変化速度はほぼ同 じであるのに対して，最外周，外周部で飛躍的に大きくな り, とくに最外周部では中間部の約 8 倍以上の平均平均変 化速度であることがわかった。さらに気孔径ごとの平均変 化速度を Fig.10に示す。とくに変化の大きい最外周部では， 気孔径ごとの変化を解析した結果，気孔径 100 200 $\mu \mathrm{m}$ 付 近を境に平均変化速度が大きく異なることがわかった。

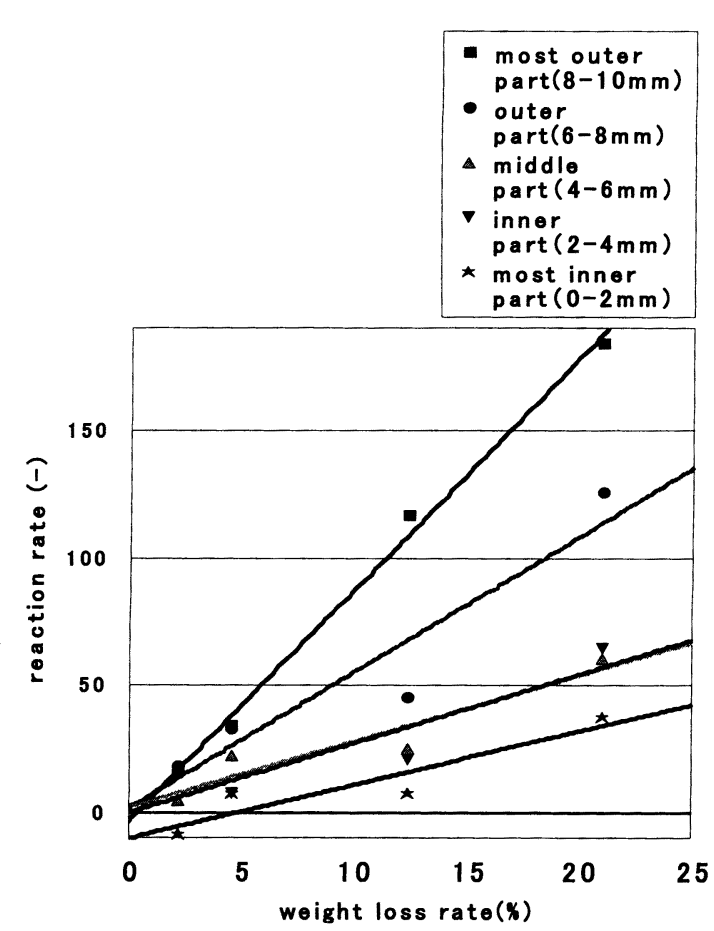

Fig. 9. The relationship between the weight loss rate and reaction rate at 5 parts of cokes. 

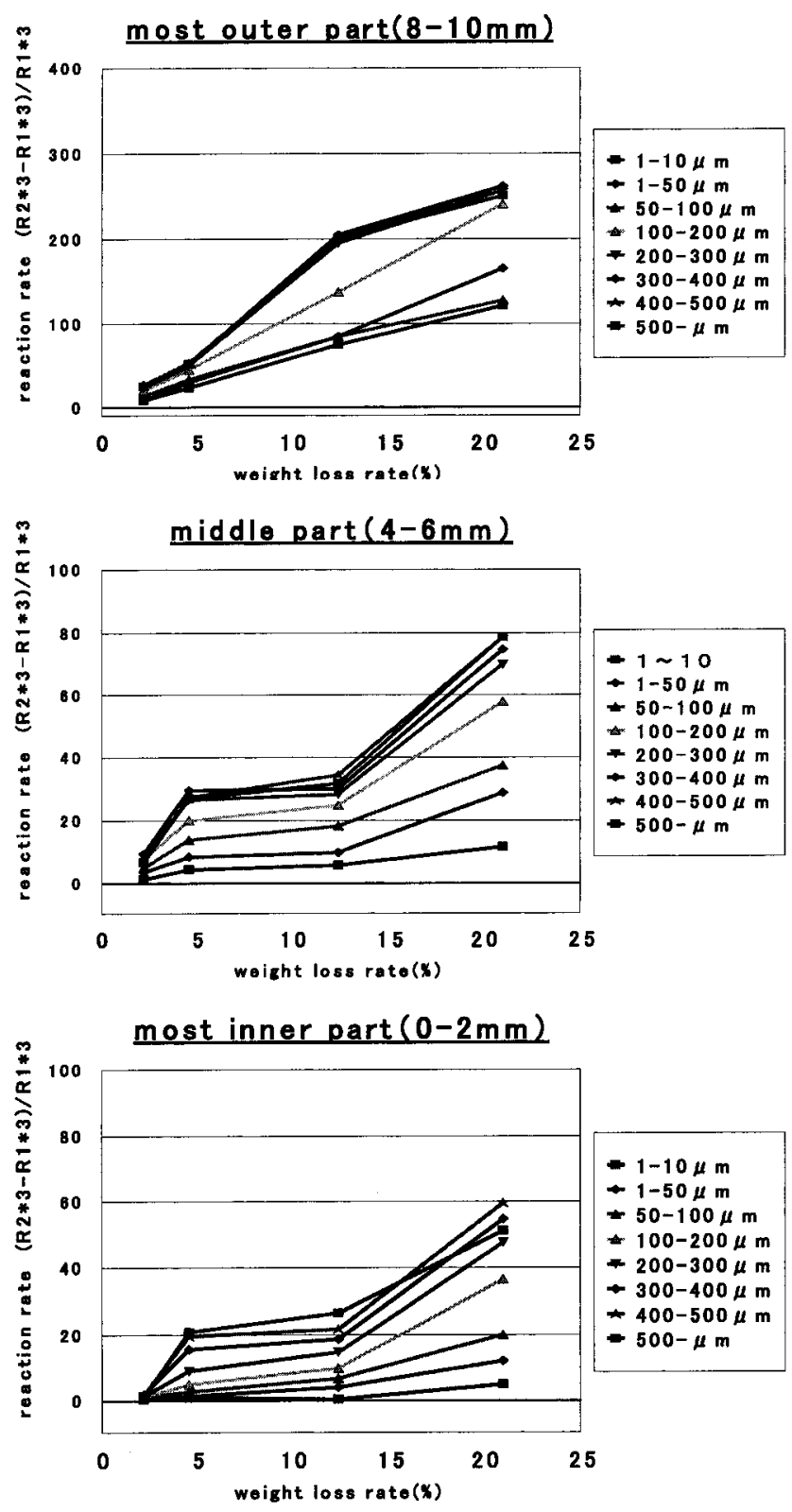

Fig. 10. The relationship between the weight loss rate and reaction rate at 3 parts of cokes with classification of pore size.

$200 \mu \mathrm{m}$ 以上の気孔径ではその平均変化速度はあまり差が ない。このことは，今回の試料と反応条件では基本的に表 面から反応が進んでいるが，とくに最外周部での $100 \mu \mathrm{m}$ 以上の気孔で優先的に反応が起こっていることを示してい る。従来の炭素材料での拡散の平均自由行程の考え方 ${ }^{31)}$ は，0.1 $\mu \mathrm{m}$ 以上の気孔ではその反応条件は一定であったが 今回の結果はそれとは異なっており，非常に興味深い。中 間部や最内周部でも, 気孔径が大きい方が多少平均変化速 度は大きいが，その差はあまり顕著ではない。

反応によって3次元的な気孔構造がどのように変化する かを検討するために，定点観測で得られた $100 \sim 200 \mu \mathrm{m}$ 程 度の気孔に着目し，イメージング像を連結させて構築した 気孔3 次元構造を Fig.11に示す。反応前の3次元気孔構造
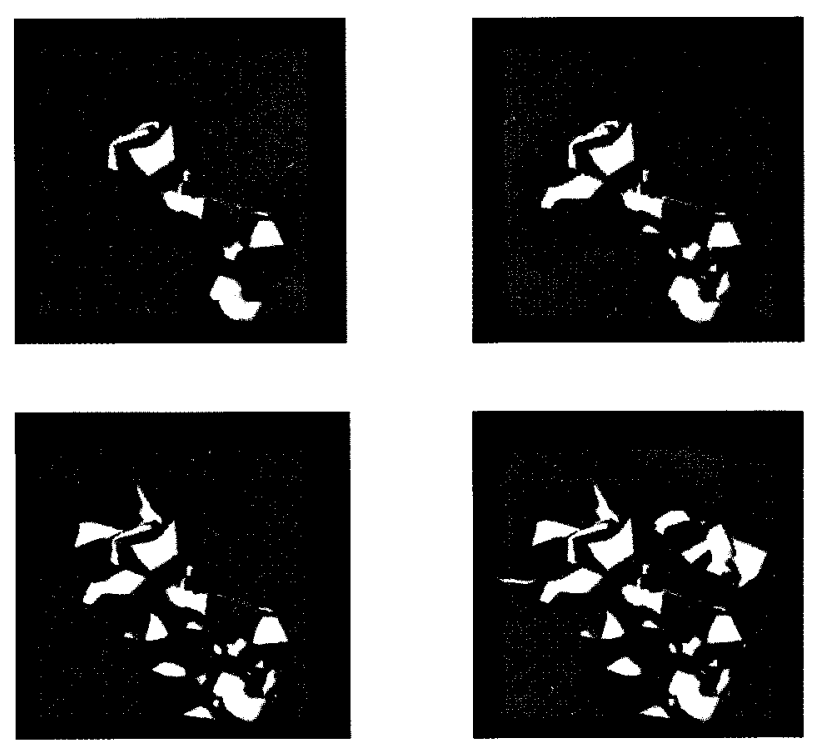

$1 \mathrm{~mm}$

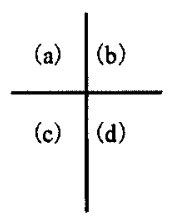

Fig. 11. Representative results of 3D pore structure for (a) NO. 2-0, (b) NO. 2-2, (c) NO. 2-3, (d) NO. 2-4 cokes.

は，筒状ではなく気孔の大きな部分と小さな部分が共存す る鉄アレイのような構造をしていることがわかる。よって， 例えば $100 \mu \mathrm{m}$ 程度の気孔とさらに小さな気孔が連結して いるような3次元構造をしている。反応が進むにつれて， 飛躍的に複雑な3次元構造になって変化しているのがわか る。先に $100 \mu \mathrm{m}$ 以上の気孔が優先的に反応が進行してい る理由は，気孔の3 次元的な複雑な構造で，とくに気孔同 士を連結させている部分が全体の反応を支配しているため と考光られる。よって，高炉内でのコークス反応やその機 構を考えた場合, 気孔構造を 3 次元的に捉えて議論する必 要があると思われる。

\section{4. 結言}

本研究を通して，以下のことが明らかとなった。

（1） NMRガスイメージング法は，数 $\mu \mathrm{m}$ 以上の気孔を 非常に鮮明を捉えることができ，反応による気孔の変化を 定点観察することも可能である。本手法は非破壊であり， 高分解能であることから，今後コークスの反応粉化機構を 検討する上で非常に有効な手法と考えられる。

(2) コークスの気孔は, 従来の水銀ポロシメータで評 価している数 $100 \mu \mathrm{m}$ 以下の気孔だけでなく，数 $100 \mu \mathrm{m}$ 以 上の大きな気孔も多数存在する。 
(3) 定点観察の結果から, 明らかに周辺部から気孔率 が上昇し, 最周辺部 $(8 \sim 9 \mathrm{~mm})$ での気孔の変化は, 周辺部 では比較的に大きな気孔からその形状を拡大し，いくつか の気孔同士が結合し，することで，さらに大きな気孔が形 成している。

（4）反応が進むにつれて存在量が増加するのは200〜 $500 \mu \mathrm{m}$ 程度の気孔である。これは，この試料およびこの 反応条件では反応が優先的にこの程度の気孔径を中心とし て起こっているためで，それを支配しているのは気孔の3 次元的な連結構造のためと思われる。

\section{文献}

1 ) T.Arima, T.Nishi and T.Okuhara: Tetsu-to-Hagané, 78 (1992), 1101.

2 ) T.Nishi, H.Haraguchi and T.Okuhara: Tetsu-to-Hagané, 76 (1990), 675.

3 ) H.Haraguchi, T.Nishi, Y.Miura, M.Ushikubo and T.Noda: Tetsu-toHagané, 70 (1984), 2216.

4 ) Y.Iwanaga and K.Takatani: Tetsu-to-Hagané, 74 (1988), 624

5 ) Y.Shigeno, M.Hong, S.Kobayashi and Y.Omori: Tetsu-to-Hagané, 74 (1988), 787.

6 ) T.Nishi, H.Haraguchi and T.Okuhara: Tetsu-to-Hagané, 73 (1987), 1869.

7 ) Y.Okuyama, T.Shiode, S.Sato and A.Kurumada: Tetsu-to-Hagané, 73 (1987), 1877.

8 ) M.Isobe, K.Suzuki, M.Tate and H.Kitagawa: Tetsu-to-Hagané, 66 (1980), 307

9 ) T.Chang and M.Tate: Tetsu-to-Hagané, 65 (1979), 479.

10) T.Chang and M.Tate: Tetsu-to-Hagané, 65 (1979), 488.
11) M.Sato, R.Murai, T.Ariyama, A.Maki, A.Shimomura and K.Mori: Tetsu-to-Hagané, 85 (1999), 717.

12) K.Yamaguchi and T.Uno: Tetsu-to-Hagané, 85 (1999), 578.

13) K.Yamaguchi and T.Uno: Tetsu-to-Hagané, 86 (2000), 11.

14) M.Nakamura, T.Ohnishi and M.Kamiya: J. Ceram. Soc. Jpn., 99 (1991), 1114

15）耐火物の組織評価と使用特性評価への試み，日本鉄鋼協会耐 火物組織評価研究会編, 日本鉄鋼協会, 東京, (1999).

16) Y.Kashiwaya, M.Takahata, K.Ishii, K.Yamaguchi, M.Naito and H.Hasegawa: Tetsu-to-Hagané, 87 (2001), 55.

17) K.Saito, K.Kunitomo, I.Komaki and K.Kato: CAMP-ISIJ, 14 (2001), 113.

18) Y.Nishi, T.Iwashita and M.Inagaki: Tanso, 201 (2002), 31.

19) H.Fujimoto, S.Itagaki, I.Shimoyama and K.Fukada: CAMP-ISIJ, 13 (2000), 933.

20) H.Fujimoto, S.Itagaki, I.Shimoyama and K.Fukada: CAMP-ISIJ, 14 (2001), 110.

21) B.Bluemich: NMR Imaging of Materials, Oxford, London, (2001).

22) B.Bluemich, P.Bluemler and K.Saito: Solid State NMR of Polymers, ed. by I.Ando and T.Asakura, Elseiver, Amsterdam, (1998), 123.

23) K.Saito, I.Komaki and K.Katoh: Tetsu-to-Hagané, 86 (2000), 111.

24) K.Saito, K.Kanehashi and I.Komaki: Annu. Rep. NMR Spectrosc., 44 (2001), 44.

25) K.Saito, M.Shinohara, K.Hasegawa and H.Tsuno: Bull. Magn. Reson., 18 (1996), 154.

26) K.Saito: Kagaku-to-Kougyou, 50 (1997), 730

27) K.Saito, K.Kunitomo, K.Fukuda and K.Kato: CAMP-ISIJ, 15 (2002), 113.

28) M.Kawakami, K.Murayama, M.Shibata, T.Takenaka and H.Toda: Tetsu-to-Hagané, 87 (2001), 48.

29) M.Kawakami, Y.Mizutani, T.Ooyabu and T.Yamamoto: CAMP-ISIJ, 15 (2002), 6

30) Y.Kashiwaya and K.Ishii: Tetsu-to-Hagané, 76 (1990), 1254.

31) G.F.Hewitt: Chem. Phys. Carbon, 1 (1965), 74. 